ऽ Or they could plan to evacuate the target area.

To help Sentinel along, in 2012 NASA signed an agreement with the B612 Foundation to provide analytical support and, once the spacecraft is in orbit, a data downlink. The space agency has an interest in Sentinel's success; it is under orders from Congress to find 90\% of all near-Earth objects 140 metres or bigger by 2020 . NASA will miss that target whether Sentinel launches or not, but a good space telescope could help to build a catalogue more quickly than ground-based surveys alone, which would need perhaps several decades.

"I don't want anybody to think that B612 is going to save the planet, but they are doing what we need to do," NASA administrator Charles Bolden said in 2013 when Congress pressed him on asteroid-detection efforts.

Yet progress has been slow. The B612 Foundation raised donations of roughly $\$ 1.2$ million in 2012 and \$1.6 million in 2013 - far short of its annual goal of $\$ 30$ million to $\$ 40$ million. NASA says that Sentinel has also missed every development milestone laid out in the 2012 agreement. In a January statement to an advisory panel, NASA said that its "reliance on the private sector for a space-based NEO survey ... is being re-examined". NASA's Lindley Johnson, director of the near-earth object programme, declined to speak to

\section{DIRECT HIT}

In the 1908 Tunguska event, an object exploded over Siberia, damaging trees across 2,000 square kilometres. If a similar event occurred above New York City, the damage would hit all five boroughs and beyond. Impact energies for different sized objects are shown.
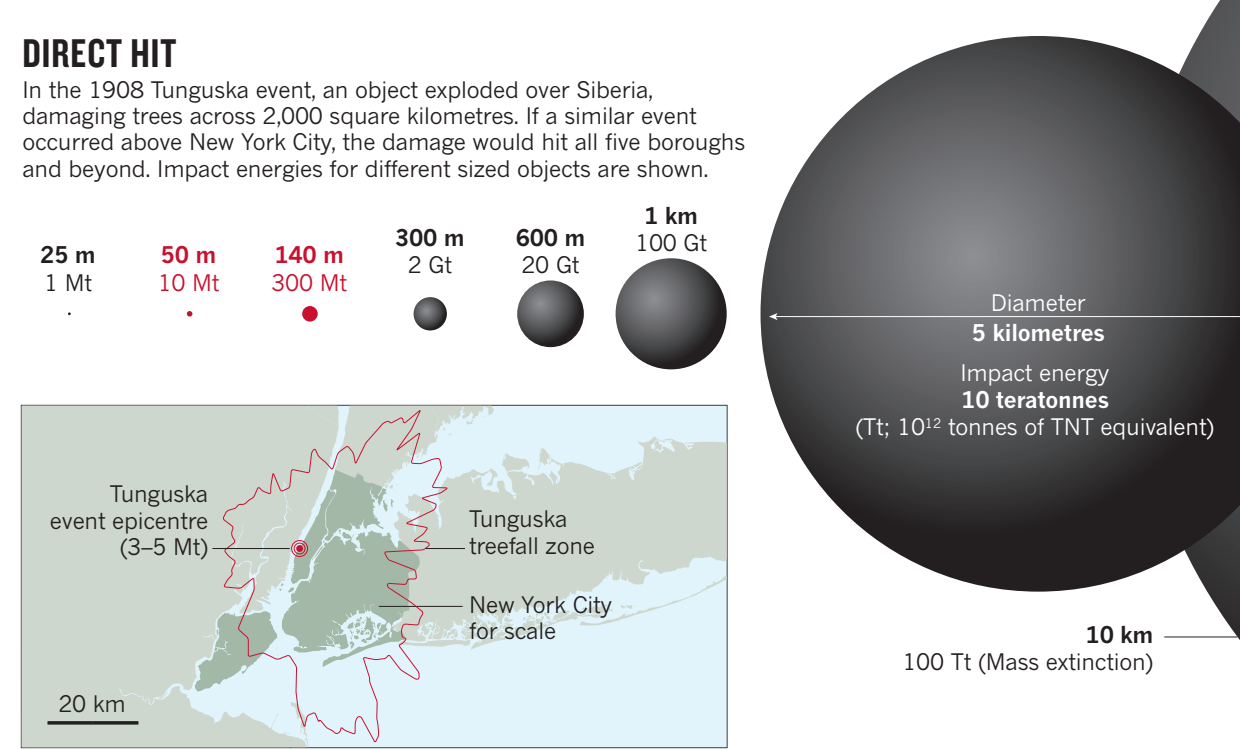

Nature, citing the ongoing discussions between the B612 Foundation and the agency.

NEOCam, meanwhile, would use an infrared telescope to search for asteroids from a vantage point between Earth and the Sun. In September, NASA will decide whether it is a finalist out of more than two dozen proposals being considered for launch by 2022 through the Discovery programme, which caps each mission's cost at $\$ 450$ million.

If Sentinel receives substantial funding soon, it could launch by late 2019, says B612 Foundation chief executive and former astronaut Edward Lu. Even if NASA terminates its agreement with the foundation, he vows to keep the project going. "Believe me, I could do a lot of other things," he says. "But I feel this is extremely important." -

\title{
Earth science wrestles with conflict-of-interest policies
}

\section{Industry-funding controversies highlight lack of standards among field's journals.}

\section{BY JEFF TOLLEFSON}

$\mathrm{T}$ The undisclosed industry ties of some authors of Earth-science papers have raised ethical questions about how the field handles conflicts of interest. The cases of global-warming sceptic Willie Soon and hydrologist Donald Siegel have inspired calls for a uniform policy on reporting funding from entities that have an interest in the outcome of research.

"The Earth-science community doesn't really have a coherent set of policies for dealing with this," says Naomi Oreskes, a science historian at Harvard University in Cambridge, Massachusetts, who co-authored a 12 June commentary ${ }^{1}$ in Environmental Science \& Technology calling for stronger disclosure rules.

Soon, a solar physicist at the Harvard-Smithsonian Center for Astrophysics co-authored a 2010 paper $^{2}$ on climate-change policy in Ecology Law Currents, but he did not disclose funding from Southern Company, an electricity provider in Atlanta, Georgia. The company has lobbied against stronger regulations to limit greenhouse-gas emissions.

The journal's editors told the Climate Investigations Center (CIC), a watchdog group in Alexandra, Virginia, that they do not have a conflict-of-interest policy, but are "exploring the possibility".

Soon also published a study ${ }^{3}$ in March in Nature Geoscience on atmospheric conditions during the Little Ice Age - a 500-year cool period that began around the 1400s - without reporting his funding. Nature Publishing Group (which also publishes Nature) says that Soon complied with its policies, which require the disclosure of financial ties that are relevant to the research in question.

But even if the study had little relevance to climate policy, Oreskes says Soon's funders benefit from any paper in a peer-reviewed journal. Such funding relationships can create an unconscious bias and should be reported, she says.
Still, having disclosure policies does not guarantee that scientists will abide by them, as the CIC found when it examined other publications that Soon listed as "deliverables" in reports to Southern Company.

In 2009, Soon and others published a study ${ }^{4}$ in the Journal of Climate on the variability of monsoons. The journal requires authors to disclose all funding sources and "any financial arrangement with a research sponsor that could give the appearance of a conflict of interest." Soon's co-authors acknowledged support from conventional granting agencies. But Soon did not report his funding from Southern Company. After the CIC released documents in February revealing Soon's industry ties, the journal amended the study to clarify his funding.

In another case, hydrologist Donald Siegel of Syracuse University in New York came under fire for a study ${ }^{5}$ that concluded that natural-gas production had not contaminated groundwater in an area of Pennsylvania dominated by 
Dells made through fracking - a process that uses pressurized fluids to shatter rock and release the trapped gas. Siegel did not disclose that the Chesapeake Energy Corporation of Oklahoma City, Oklahoma, had paid him to analyse the data. Environmental Science \& Technology, which published the analysis, posted a correction in April after the media revealed Siegel's links to the company.

Siegel says that he thought that this relationship was obvious, because he was working on a summer contract with the company's consultants, some of whom were listed as co-authors. "I never really anticipated this, but perhaps I was naive," Siegel says. "Because of the public nature of some of this science, I think we probably need a much tighter rein on what disclosure is."

Disclosure demands are coming from both sides of the aisle: climate sceptics have objected to a Nature Climate Change study ${ }^{6}$ that analysed some of the US Environmental Protection Agency's greenhousegas regulations, because it was written by researchers who have received grants from the agency - even though the grants are listed in a public database.

Some experts suggest that Earth scientists should look to the biomedical community for guidance. Many biomedical journals require authors to fill out a common disclosure form that publishers developed in 1978 and have continued to update. And universities and hospitals often require medical researchers to report each year on their financial arrangements with industry.

Eric Campbell, a sociologist at Harvard's Edmond J. Safra Center for Ethics, says that biomedical scientists, funding agencies and journals have better-established disclosure policies because their work often involves human participants, and because of the strong financial ties between academia and the pharmaceutical industry.

There are no plans yet for the Earthscience community to develop disclosure standards. But there may be nascent backing for such an effort. Véronique Kiermer, director of author and reviewer services at Nature Publishing Group, says that the publisher "would be supportive of discussions in the Earth-sciences community about the specific challenges of the field and a framework for the standards of transparency it requires."

Campbell says that such a group discussion would be useful. "You don't want the individual with the conflict making decisions about what they should do about it." -

1. Oreskes, N. et al. Environ. Sci. Technol. http:// dx.doi.org/10.1021/acs.est.5b02726 (2015).

2. Soon, W. \& Legates, D. R. Ecol. Law Curr. 37, 1-9 (2010).

3. Yan, H. et al. Nature Geosci. 8, 315-320 (2015).

4. Liu, J. et al. J. Clim. 22, 2356-2371 (2009).

5. Siegel, D. I. et al. Environ. Sci. Technol. 49, 4106-4112 (2015).

6. Driscoll, C. T. et al. Nature Clim. Change 5, 535-540 (2015).

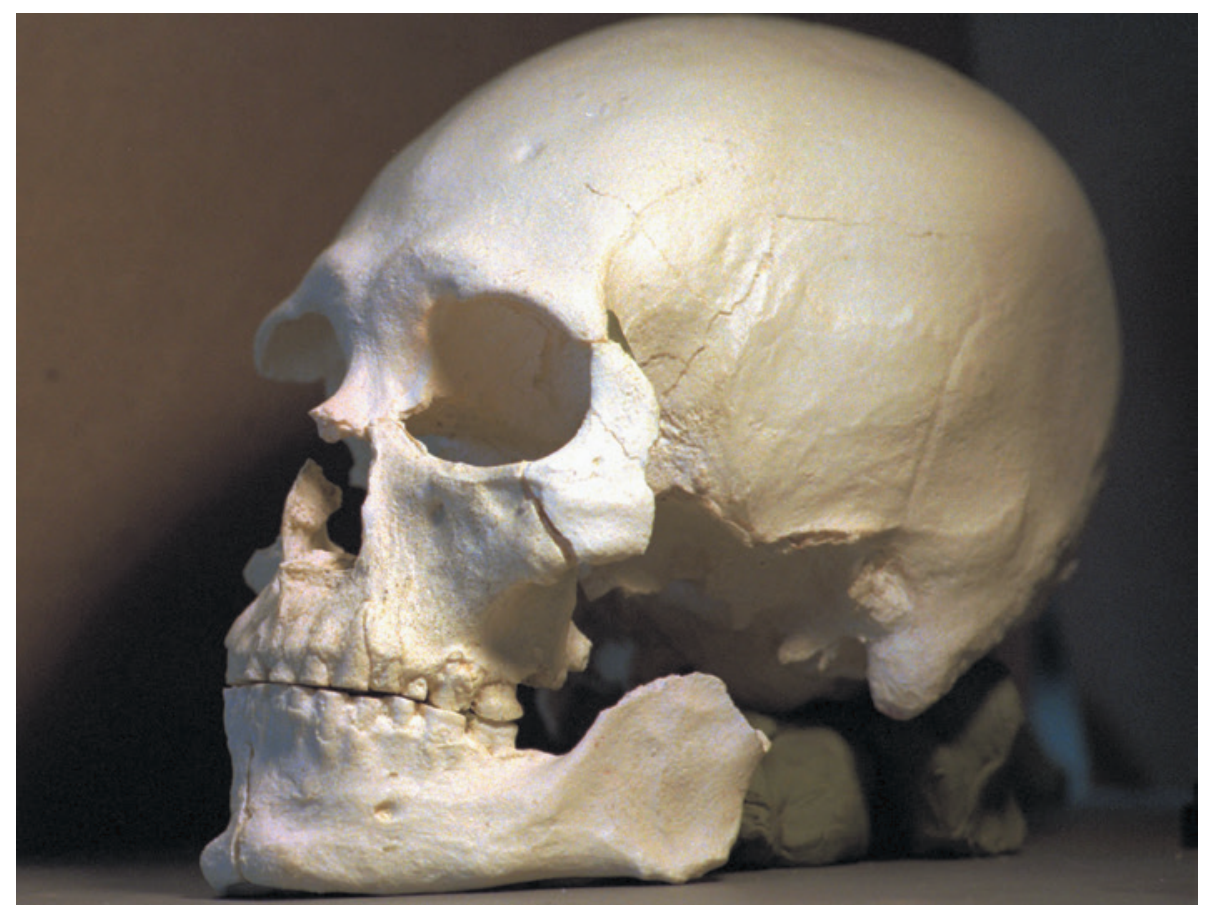

A plastic cast of the skull of Kennewick Man.

ANCESTRY

Genome results rekindle legal row

\section{‘Kennewick Man’ sequencing shows Native American roots.}

\section{BY EWEN CALLAWAY}

$\mathrm{T}$ The genome of a famous 8,500-year-old North American skeleton, known as Kennewick Man, shows that he is closely related to Native American tribes that have for decades been seeking to bury his bones. The finding seems likely to rekindle a legal dispute between the tribes and the researchers who want to keep studying the skeleton. Yet it comes at a time when many scientists - including those studying Kennewick Man - are trying to move past such controversies by inviting Native Americans to take part in their research.

"The controversy has been painful for lots of people; tribal members and scientists as well," says Dennis O’Rourke, a biological anthropologist at the University of Utah in Salt Lake City.

Soon after the skeleton's bones were unearthed in 1996, near the shores of the Columbia River near Kennewick, Washington, several local tribes demanded the return of Kennewick Man, whom they dubbed the Ancient One. The US Army Corps of Engineers - the federal agency that manages the land where the remains were found - sided with the tribes, citing a 1990 law that mandates the return of Native American remains and artefacts to affiliated tribes: the Native American Graves Protection and Repatriation Act (NAGPRA).

Several archaeologists and anthropologists sued the US government to stop the return, arguing that Kennewick Man was too old to be connected to the tribes. In 2002, a federal judge ruled that NAGPRA did not apply because the US goverment had not established that the tribes had a cultural affiliation with Kennewick Man. The decision was affirmed by a US Appeals Court in 2004.

A team led by Eske Willerslev, a palaeogenomicist at the Natural History Museum of Denmark in Copenhagen, used cutting-edge methods to extract snippets of DNA from a flake of finger bone and then sequence the genome. The researchers then compared the genome to that of members of dozens of groups from across North and South America, including several members of the Confederated Tribes of the Colville Reservation, one of the five groups seeking Kennewick Man's reburial (M. Rasmussen et al. Nature http://doi.org/5jb; 2015). Members of the 